\title{
Kuliner Sebagai Identitas Budaya: Perspektif Komunikasi Lintas Budaya
}

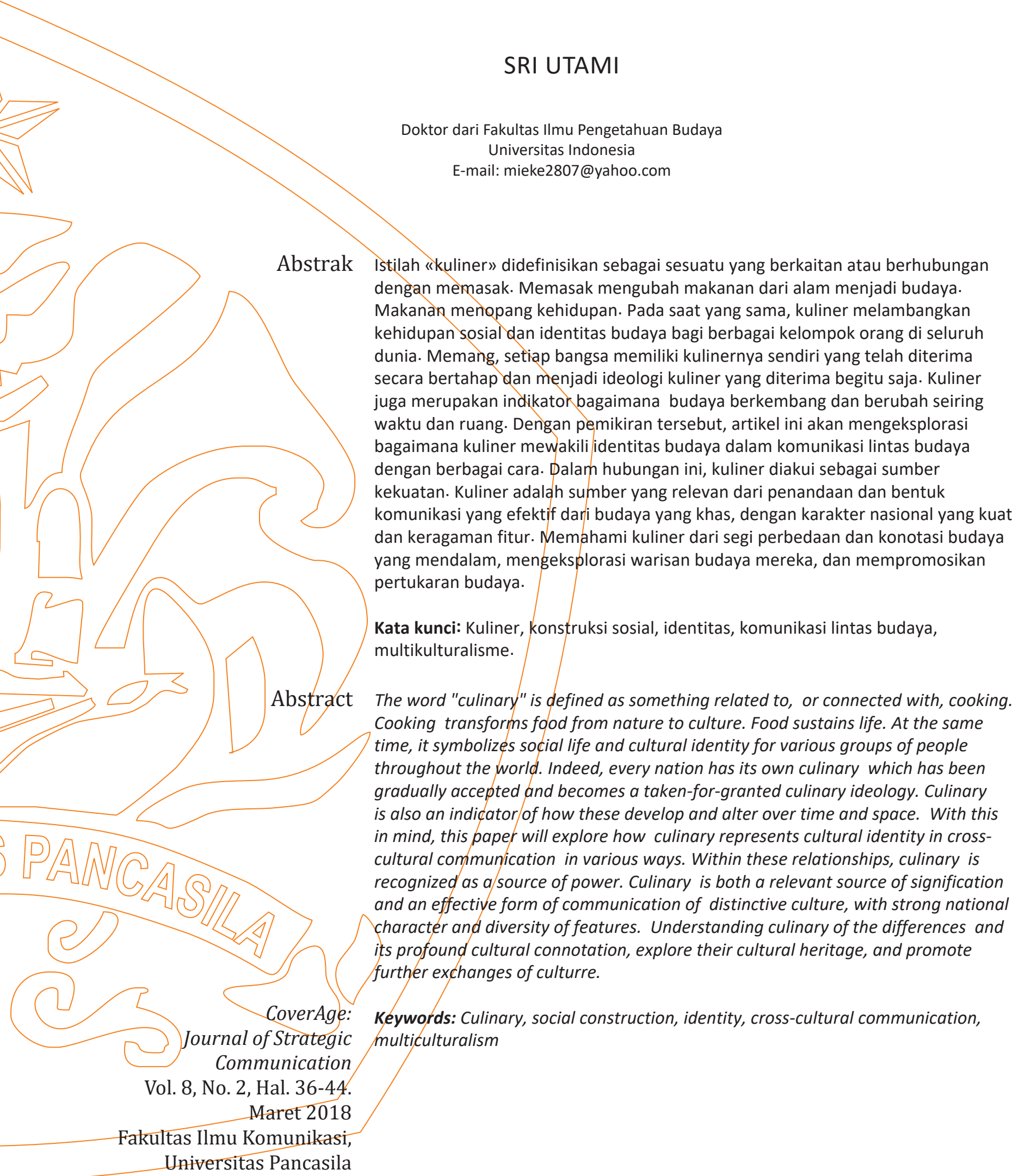

Diterima 5 November 2017

Disetujui 6 Februari 2018 


\section{PENDAHULUAN}

Kuliner yang menjadi sorotan dalam artikel ini, secara etimologis merupakan terjemahan dari kata dalam bahasa Inggris 'culinary'. Kata ini berasal dari bahasa Latin 'culinarius' yang didapat dari kata 'culina' yang berarti dapur, tempat memasak makanan. Memasak memiliki makna universal, yaitu transformasi dari alam menuju ke budaya. Selain itu, memasak juga merupakan 'bahasa' yang kita gunakan untuk berbicara tentang diri kita dan tempat kita berada di dunia. Mungkin kita bisa memetik ungkapan Descartes dan mengubahnya menjadi "Saya makan, maka saya ada" (Woodward [ed.], 1999: 31-32).

Apa yang kita makan menunjukkan banyak hal tentang siapa diri kita, serta tentang budaya dari keberadaan kita. Makanan adalah medium dari masyarakat untuk menyatakan tentang dirinya. Ungkapan "we are what we eat" dan "we are what we don't eat" menunjukkan suatu identitas dalam budaya dari satu komunitas, bahkan secara lebih luas dapat menunjukkan identitas suatu bangsa. Lebih tajam lagi, ungkapan dari Jean Anthelme Brillat-Savarin, "Tell me what you eat, I'll tell you who you are". Jean Anthelme Brillat-Savarin (1 April 1755-2 February 1826) seorang pengacara Perancis dan politisi, namun memperoleh ketenaran sebagai epicure dan gastronomer.

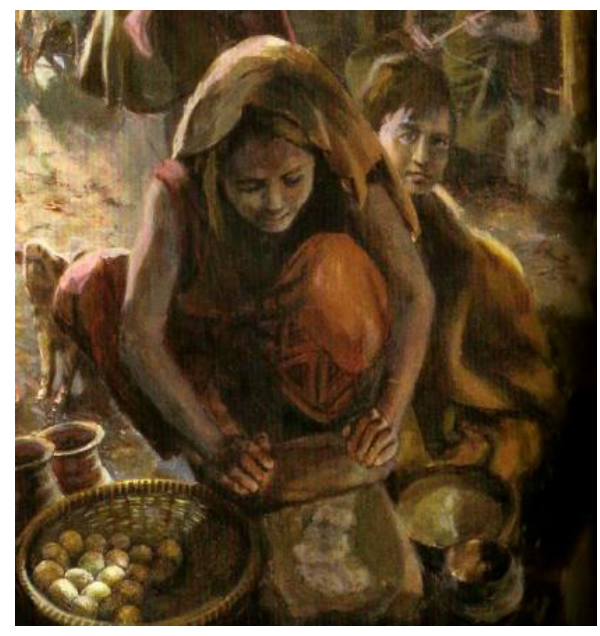

Edo ergo sum - I eat, therefore I am Gambar 1. Ungkapan terkait Kuliner

(Sumber: Diolah oleh penulis)

Dari ulasan tersebut di atas, makanan walau nampak sepele, ternyata memilki peran penting dalam semua aspek kehidupan masyarakat. Makanan adalah faktor motivasi yang mendorong tindakan secara individual pada suatu komunitas tertentu atau keseluruhan masyarakat. Makanan adalah bagian dari pola siklus hidup. Makanan dapat dikatakan sebagai pengikat keterpisahan satu komunitas dengan komunitas yang lain. Ketika berada jauh dari rumah, makanan mempertautkan rasa memiliki dalam dunia yang asing. Makanan berfungsi sebagai kunci untuk mengikat. Kuliner merupakan konsep tentang makanan, dengan demikian kuliner merupakan elemen dari kebudayaan, yang berkaitan dengan akar historis, kolonialisme, mitos, agama, dan nilai dalam suatu masyarakat.

Dari tinjauan pustaka tentang kuliner terdapat bukti adanya proses komunikasi lintas budaya, seturut dengan pengaruh globalisasi. Proses ini merupakan suatu dialog antar identitas budaya dari masyarakat dengan munculnya suatu identitas multikultural. Kaitan identitas budaya dan kuliner menyeruak di tengah peradaban global. Menurut Tomlison, globalisasi merupakan suatu proses yang tidak dapat dihindari oleh masyarakat dunia secara keseluruhan. Globalisasi adalah proses yang multidimensional, yang secara bersamaan mampu menginduksi bidang ekonomi, politik, lingkungan, institusionalisasi teknologi, dan budaya (Tomlinson, 2007: 150).

Dalam masyarakat terjadi interaksi kebudayaan yang berbeda-beda, merupakan suatu keniscayaan bahwa penyebaran budaya yang tak terpisahkan dengan adanya kekuasaan. Bentuk paling mendasar dari kekuasaan pada hakikatnya adalah membentuk pikiran manusia. Dengan pengaruh pada pikiran manusia maka akan menentukan cara manusia bertindak. Menurut Tomlinson budaya secara instrinsik bersifat constitutive terhadap globalisasi. Budaya dalam hal ini didefinisikan sebagai konstruksi secara sosial, yang digambarkan sebagai representasi, pengalaman hidup dan konteks yang mengarah pada kehidupan secara individual maupun kolektif. Kaitan budaya dan globalisasi adalah ketika bagaimana secara kultural perilaku-perilaku lokalitas kemudian bisa terglobalkan sebagai konsekuensi dari interkoneksitas globalisasi.

Penyebaran budaya terjadi lewat komunikasi antar budaya yang semakin luas membuat budayabudaya tertentu kemudian ter-universal-kan bahkan diterapkan dalam aspek kehidupan seperti dalam politik dan hukum. Manusia pada masa kini tiada mungkin menghindar dari pengaruh globalisasi yang menimbulkan kekuatan yang sangat signifikan dalam menciptakan dan mengembangkan identitas budaya. Permasalahan dalam artikel ini apa dan bagaimana pengaruh kuliner sebagai identitas budaya dalam kehidupan manusia didunia, dan 
mengapa komunikasi lintas budaya dapat menjadi agen perubahan kuliner sebagai identitas budaya. Adapun tujuan penulisan artikel ini agar dapat lebih memahami kuliner sebagai identitas budaya yang terus menerus mengalami proses perubahan dan akan memengaruhi kualitas hidup manusia dalam globalisasi.

Secara ringkas alur pemikiran dalam paper ini dapat dilihat pada gambar 2 .

\section{PEMBAHASAN}

\section{Pemahaman tentang Kuliner}

Kuliner merupakan elemen budaya dari suatu bangsa yang sangat mudah dikenali sebagai identitas suatu masyarakat. Kuliner merupakan salah satu unsur dari budaya dan menunjukkan adanya hubungan sosial. Apa yang kita makan, dengan siapa kita makan, dan bagaimana penyajian makanan menunjukkan peranan yang penting dalam memaknai relasi sosial. Makan adalah bentuk dasar dari semua transaksi dengan pihak lain dan setiap pertukaran obyek (Woodward [ed.], 1999:31). Dalam hal ini saya sependapat pada ungkapan bahwa setiap negara, bahkan setiap kelompok masyarakat memiliki kuliner sesuai dengan seleranya masing-masing dan sesuai dengan kondisi alamnya. Secara spontan pikiran kita akan mengarah pada suatu makanan spesifik bila menyebut selera makan tertentu. Lebih lanjut, Anna Meigs menunjukkan bahwa kuliner adalah hasil konstruksi budaya yang mengeksplorasi bagaimana makanan dan makan dipahami sebagai alat yang menyatukan beragam organisme, baik fisiologis dan mistis, dalam kehidupan tunggal (Meigs, 1997: 95106).

Makanan selain merupakan kebutuhan biologis agar manusia dapat bertahan hidup, juga merupakan kebutuhan sosial dan budaya manusia dalam komunitas atau masyarakat. Pilihan makanan untuk asupan makanan dibentuk oleh faktor-faktor sosial dan budaya yang memberi makna simbolis pada makanan. Faktor-faktor budaya merupakan bagian dari pengalaman manusia yang selalu berkembang dan berubah. Dalam artikel ini, penulis akan membahas bagaimana proses membentuk produksi, distribusi, persiapan, dan konsumsi makanan lintas budaya dalam banyak cara. Dalam hubungan ini, kuliner dapat dimaknai sebagai sumber kekuasaan dalam heterogenitas hubungan lintas budaya.

Hasil silang budaya terjadi dalam 'dialog' antar kuliner dari bangsa-bangsa yang saling bertemu. Agen dari 'dialog' yang dominan adalah media komunikasi yang saat ini makin terbuka dan merasuk dalam kehidupan manusia di seluruh pelosok dunia. Melalui komunikasi lintas budaya, kuliner berkembang dengan membentuk banyak pilihan dengan memperluas inovasi gastronomi,

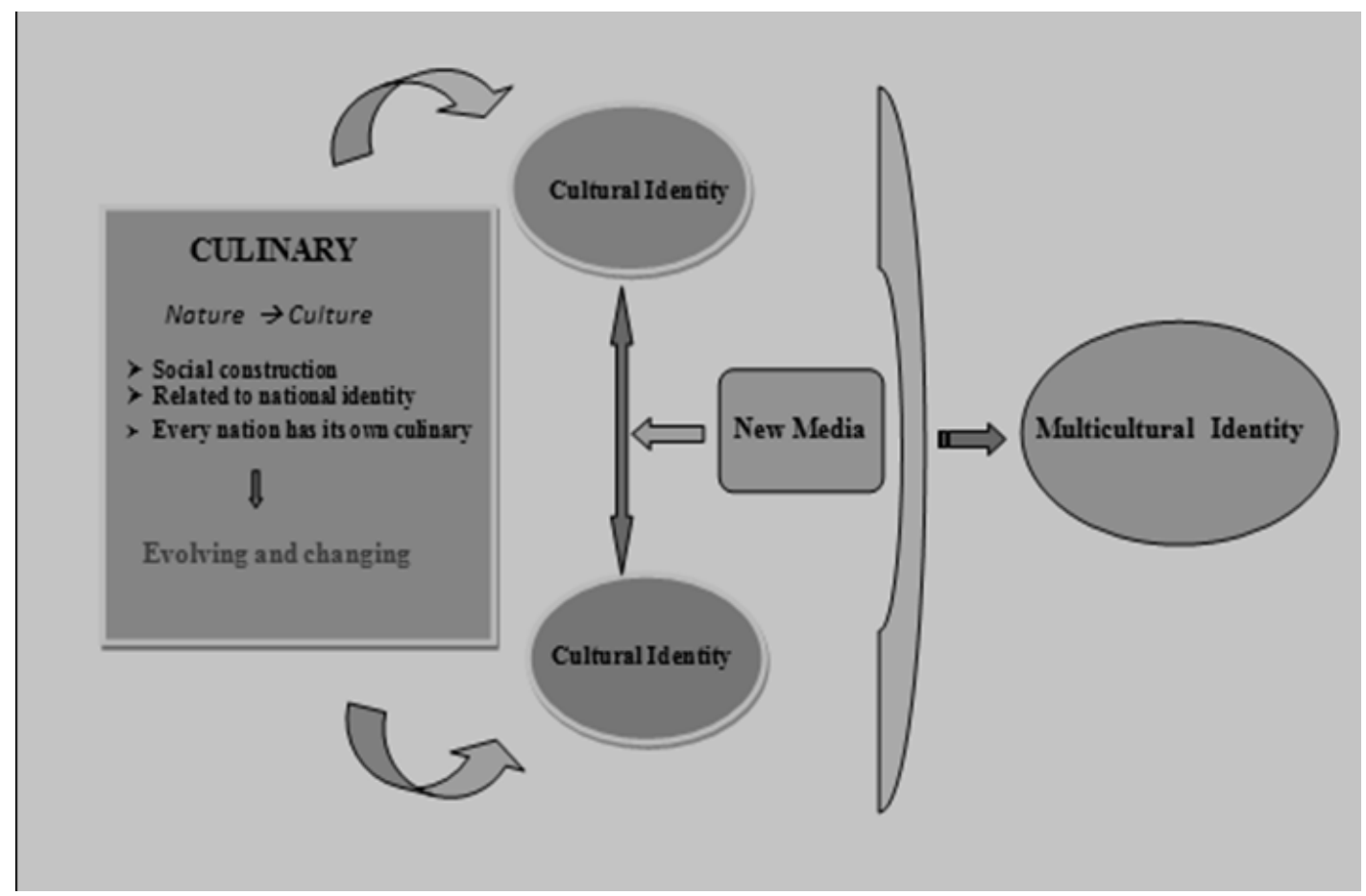

Gambar 2. Alur Pemikiran Penelitian 
memadukan multietnis makanan. Untuk itu dilakukan banyak penelitian dalam konteks literal produksi dan konsumsi ke dalam kolosal budaya yang melintasi batas antara antropologi, sosiologi, seni, dan humaniora.

Makanan memiliki banyak arti dan bahwa "persiapan, ritual, bau, kondisi sosial, perubahan iklim, serta di manamakanan itu ditabur, dikumpulkan, disusun, dan dimakan adalah bentuk ekspresi budaya dan identitas" (Bentley, 2007: 215). Sedangkan menurut Brian Street, budaya merupakan proses aktif dalam pembentukan makna, dengan mengemukakan pemikiran bahwa budaya adalah kata kerja bukan kata benda (culture is a verb, not a noun) (Street, 1993: 23-43). Bila budaya adalah hasil konstruksi berarti bisa didekonstruksi. Berarti budaya bukan sesuatu benda riil, tetapi sesuatu imaginasi yang kita bentuk agar dapat diterima dalam dunia di sekitar kita. Dari pengertian ini, budaya bukan sesuatu yang statis, melainkan sesuatu yang aktif. Terbukti bisa didekonstruksi, yang berarti bisa berkembang dan berubah. Demikian juga halnya dengan kuliner sebagai identitas budaya, terus berkembang dan berubah.

\section{Identitas Budaya}

Eduardo Mendieta mengatakan:

"Our identities are never discovered. They are always constituted, constructed, invented, imagined, imposed, projected, suffered, and celebrated. Identities are never univocal, stable, or innocence. They are always an accomplished and ceaseless project. For this reason, in the process of constituting them and negotiating them, we discover that we were like we never imagined to have been." (Alcoff \& Mendieta [eds], 2000: 414)

Ungkapan Eduardo Mendieta di atas menjadi awalan untuk mengulas masalah identitas, yang dalam kekinian marak menjadi topik mengemuka berkaitan dengan perdebatan berbagai kajian, terutama yang berkaitan dengan pascakolonialisme, multikulturalisme, dan globalisasi. Menurut Mendeita, multikuturalisme dan globalisasi secara kontemporer berkelindan dengan suatu wacana yang teramat kompleks.

Pengertian tentang identitas merupakan suatu kombinasi paradoksial antara yang sama dan yang lain (sameness and difference). Merunut dari asal kata identitas dari bahasa Latin "idem' yang mempunyai arti 'sama'. Dari arti etimologis ini, kita mendapat term 'identical', yang memiliki arti penting bahwa kita tidak hanya identik dengan diri sendiri (the same being from birth to death), tetapi kita juga identik dengan yang lain. Dengan demikian kita secara umum memiliki identitas sebagai manusia, tetapi juga sebagai perempuan atau laki-laki, orang Indonesia, ras berkulit coklat, dan sebagainya. Pada saat yang bersamaan, terdapat aspek identitas yang lain, yang menunjukkan keunikan, perbedaan dengan yang lain. Singkat kata, tak seorangpun hanya memiliki satu identitas. Hal ini berarti terdapat kombinasi dari kegandaan ini, tidak sekedar penambahan jumlah identitas. Berbagai bentuk identitas dipandang sebagai interaktif dan saling konstitutif, juga bersifat dinamis. Beberapa bentuk identitas dipahami sebagai mutually exclusive, sehingga tidak mudah untuk mengombinasikannya (Lawler, 2008: 3).

Semua identitas merupakan suatu bentuk konstruksi sosial, sehingga menjadi sumber makna dan pengalaman manusia. Hal ini dinyatakan oleh Calhoun:

"Tiada orang tanpa nama, serta tanpa bahasa dan tanpa budaya yang menjadi pembeda antara diri dan liyan. Pengetahuan tentang diri senantiasa merupakan hasil konstruksi dan tidak pernah sama sekali terpisah dari klaim bagi cara khas untuk diketahui yang lain." (Castel, 1997: 172)

Identitas menjadi suatu sumber yang lebih kuat bagi pemaknaan dirimanusia daripada perannya, yang disebabkan proses konstruksi diri dan individulisasi yang melibat. Dalam pengertian sederhana, identitas membentuk makna dan semua identitas adalah dikonstruksi. Yang menjadi pertanyaan penting, yaitu bagaimana, dari apa, oleh siapa, dan untuk apa. Konstruksi identitas menggunakan materi pembentuk yang dipetik dari sejarah, dari geografi, dari biologi, dari institusi produktif dan reproduktif, dari memori kolektif, dari khayalan pribadi, dari perangkat kekuasaan, dan revelasi religi. Perorangan, kelompok sosial, dan masyarakat memproses keseluruhan materi pembentuk, dan menata ulang sesuai dalam struktur sosial. Konstruksi sosial atas identitas selalu berkaitan dengan kekuasaan. Tak mudah untuk menentukan siapa yang membentuk adanya jenis identitas yang beragam. Ini merupakan term abstrak, dan berhubungan dengan konteks sosial.

Konstruksi identitas, sepanjang menyangkut pengalaman kolektif yang berbeda, seperti identitas Timur atau Barat, hampir selalu melibatkan konstruksi antitesis dari liyan yang aktualitasnya 
selalu menjadi obyek interpretasi dan reinterpretasi yang berlangsung tanpa henti. Kita tidak bisa menghilangkan rasa permusuhan terhadap identitas liyan ini, karena setiap zaman dan setiap masyarakat selalu menciptakan kembali liyan dalam wujud dan bentuk yang beraneka ragam. Identitas diri atau liyan tidak berada dalam proses statis, melainkan berlangsung secara historis, sosial, intelektual, dan politis. Proses ini kemudian mewujud menjadi persaingan tanpa henti. Dari persaingan identitas ini, lahir semacam proses interpretatif yang berujung pada legitimasi identitas-identitas liyan, yang berbeda dengan identitas diri. Konstruksi identitas hampir selalu diiringi dengan upaya untuk mendisposisi kekuatan dan ketidakberdayaan pada kelompok masyarakat tertentu. Identitas manusia tidak dapat hanya dilihat sebagai identitas alamiah dan stabil, melainkan juga dikonstruksi, bahkan tak jarang diciptakan secara langsung. Suatu proses penciptaan identitas berlangsung tanpa henti.

Mengurai masalah identitas, dengan mendapatkan suatu proses 'menjadi' dan memiliki suatu kemiripan dengan apa yang kita pikirkan. Dalam hal ini antara 'what we are' dan 'what we have become' menjadi faktor lain, yaitu bagaimana kita melihat identitas dan bagaimana kita akan 'menjadi' Identitas memiliki banyak hubungannya dengan kesan (images), khayalan (imaginaries), dan imajinasi (imagination). Dari uraian tersebut di atas, identitas merupakan sesuatu yang secara aktual terbentuk melalui proses tidak sadar yang melampaui waktu, bukan kondisi yang terberi begitu saja dalam kesadaran semenjak lahir. Dalam identitas itu, terdapat sesuatu yang bersifat 'imajiner" atau difantasikan mengenai keutuhannya. Identitas menyisakan ketidaklengkapan, selalu 'dalam proses sedang dibentuk' (Hall, 1994: 32).

Saya setuju dengan pendapat bahwa identitas selalu dalam proses 'menjadi' dan tidak akan pernah selesai secara tuntas. Ini berarti bahwa identitas merujuk pada suatu titik temu antara wacana dan praksis yang berupaya pada satu sisi untuk memperjelas kedudukan sebagai subyek dari wacana tertentu, dan pada sisi lain sebagai proses yang menentukan subyektivitas. Identitas adalah suatu imajinasi yang lahir ketika kita dipandang berbeda oleh pihak lainnya. Artinya, identitas hadir ketika diri berhadapan dengan sosok liyan. Sebagai sebuah proyek, identitas bermakna apa yang kita pikirkan sekarang dipandang dari keadaan masa lampau dan masa kini, sejalan dengan pikiran, hendak menjadi apa, yang merupakan lintasan antara harapan bagi masa depan. Inilah yang menjadi dasar pokok untuk mengulas kuliner sebagai identitas budaya yang mempunyai semua faktor yang diuraikan di atas.

\section{Komunikasi Lintas Budaya}

Dengan pesatnya laju perkembangan teknologi trasportasi dan informasi, memungkinkan manusia di berbagai penjuru dunia saling mengenal dan berhubungan. Faktor penting dalam hal ini adanya dialog tentang berbagai hal, terutama untuk saling memahami budaya dari orang lain. Budaya asing telah menjadi bagian penting bagi penduduk suatu negeri. Edward T. Hall dalam bukunya yang berjudul The Silent Language (1959) mengatakan, kebudayaan adalah komunikasi dan komunikasi adalah kebudayaan. Pendapat tersebut menandakan suatu komunitas manusia yang tidak bisa terbangun tanpa adanya komunikasi. Budaya sendiri tercipta karena komunikasi yang juga terbangun dari komunitas manusia. Alam, tanda, dan berbagai produk konsumsi manusia berawal dari cara pandang bagaimana sesuatu bisa dikomunikasikan. Dengan kata lain, tak mungkin memikirkan komunikasi tanpa memikirkan konteks dan makna kulturalnya.

Pendapat senada diungkapkan oleh Ngugi wa Thiong'o bahwa komunikasi menciptakan budaya dan budaya adalah prasarana dari komunikasi. Bahasa memengaruhi budaya, dan budaya memengaruhi keseluruhan nilai-nilai yang kita miliki dan keberadaan kita di dunia (Ngugi, 1986: 15-16). Sedangkan Brian V Street mengemukakan bahwa culture is a verb, not a noun, kebudayaan merupakan proses aktif dalam membentuk makna (Street, B., 1993, 23-43). Dari pemikiran tentang budaya tersebut, dapat dimaknai bahwa budaya merupakan bagian tak terpisahkan daripada eksistensi manusia. Melalui budaya dan apa yang ditinggalkannya, kita dapat menguak keberadaan manusia pada masa lampau. Kepemilikan budaya dalam diri manusia sangat berperan dalam pembentukan identitas budaya. Lebih mendalam dapat kita ketahui bahwa budaya berkenaan dengan cara manusia hidup. Hal ini disebabkan karena budaya muncul dari tindakantindakan yang menandakan bahwa mereka itu "hidup", seperti berpikir, merasa, dan memercayai.

Larry A. Samovar mengemukakan bahwa budaya adalah suatu konsep yang membangkitkan minat. Secara formal, budaya juga di definisikan sebagai tatanan pengetahuan, pengalaman, kepercayaan, nilai, sikap, makna, hierarki, agama, waktu, peranan, hubungan ruang, konsep alam semesta, objekobjek materi, dan milik yang diperoleh sekelompok 
besar orang dari generasi ke generasi melalui usaha individu atau kelompok. Untuk mengkaji komunikasi antarbudaya, Samovar dan Porter menyatakan bahwa perlu ada pemahaman hubungan antara kebudayaan dengan komunikasi. Melalui kebudayaan, manusia belajar berkomunikasi serta memandang dunia mereka melalui kategori-kategori, konsep-konsep, dan label-label yang dihasilkan budaya. Kemiripan budaya dalam perspektif ini memungkinkan pemberian makna yang mirip terhadap suatu objek sosial atau peristiwa. Oleh karena itu, hubungan antar budaya dan komunikasi bersifat timbal balik, di mana keduanya saling memengaruhi (Samovar \& Porter, 1991: 25-26).

Dari uraian di atas, dapat dipahami bahwa komunikasi lintas budaya terjadi dalam ruang lintas budaya yang berbeda. Dalam hal ini akan muncul suatu bentuk komunikasi yang unik di dalamnya. Keunikan ini turut mempertimbangkan peranan dan fungsi budaya dalam proses komunikasi. Komunikasi mutlak dibutuhkan dan dilakukan oleh manusia, namun perbedaan identitas budaya pada setiap kelompok manusia memunculkan berbagai kerumitan. Budaya dan komunikasi berinteraksi secara erat dan dinamis. Intinya budaya adalah komunikasi, karena budaya muncul melalui komunikasi. Akan tetapi pada gilirannya budaya yang tercipta pun memengaruhi cara berkomunikasi anggota budaya bersangkutan.

Hubungan antara budaya dan komunikasi bersifat timbal-balik. Budaya tak akan eksis tanpa komunikasi dan komunikasi pun takkan eksis tanpa budaya. Selanjutnya harus diakui bahwa budaya menentukan cara kita berkomunikasi: topik pembicaraan, siapa boleh berbicara atau bertemu dengan siapa, bagaimana dan kapan, bahasa tubuh, konsep ruang dan waktu. Jadi dalam negosiasi antar budaya, proses komunikasi yang terjadi lebih rumit daripada dalam negosiasi dengan orang yang berbudaya sama. Kepekaan terhadap perbedaan budaya dan kesadaran bagaimana perbedaan tersebut, menjadi faktor penting dalam komunikasi lintas budaya (Mulyana \& Rakhmat [ed], 2010: 3-12).

Menurut Samovar, komunikasi lintas budaya adalah komunikasi antara orang yang berbeda kebudayaannya, misal pada suku bangsa, etnik, dan ras atau kelas sosial. Komunikasi ini terjadi di antara produser pesan dan penerima pesan yang berbeda latar belakang kebudayaannya. Hal ini berarti, komunikasi lintas budaya adalah proses pertukaran pikiran dan makna antara orang-orang yang berbeda budaya. Lebih lanjut dikatakan bahwa komunikasi lintas budaya pada dasarnya mengkaji bagaimana budaya berpengaruh terhadap aktivitas komunikasi: apa makna pesan verbal dan nonverbal menurut budaya-budaya bersangkutan, apa yang layak dikomunikasikan, bagaimana cara mengomunikasikannya kapan mengomunikasikannya, dan sebagainya (Samovar \&Porter, 1976: 44).

\section{Kuliner Sebagai Identitas Budaya dalam Globalisasi}

Setiap bangsa memiliki budaya kuliner yang berbeda yang merupakan karakter nasional yang kuat dan keragaman wujudnya. Perbedaan dalam budaya kuliner juga memunculkan adanya komunikasi lintas budaya. Sebagai contoh dalam memahami perbedaan kuliner China dan kuliner Eropa menghasilkan konotasi budaya yang menelisik warisan budaya dan memancarkan perubahan budaya secara complementary and compatible. Pemikiran postmodern memengaruhi perkembangan kuliner dalam globalisasi. Dalam karya Jean François Lyotard "The Postmodern Condition," terdapat penegasan bahwa pengetahuan dan kebenaran tidak pasti dan bisa diubah. Hal ini nyata nampak terjadinya pengaruh pada perubahan kuliner secara global, terutama dengan dipicu perkembangan teknologi informasi. Budaya postmodern merasuk yang mempertanyakan dunia, mempertimbangkan kebenaran dan realitas yang relatif dan tidak tetap, serta menolak adanya pembatasan.

Keterkaitan antara budaya dan globalisasi, diperjelas dalam pemikiran Douglass Kellner dalam "Globalization and the Postmodern Turn" dengan ulasan bahwa dalam globalisasi terjadi pengikisan budaya dan tradisi lokal melalui budaya global. Selanjutnya Kellner menyatakan bahwa selain pengembangan ekonomi pasar global baru dan sistem pergeseran negara-bangsa, kebangkitan budaya global. Globalisasi melibatkan penyebaran teknologi baru yang memiliki dampak luar biasa pada ekonomi, pemerintahan, masyarakat, budaya, dan kehidupan sehari-hari. Kuliner dalam globalisasi mudah ditelusuri dari kolonialisme pada masa lalu, karena secara historis banyak makanan dan praktek makan telah dipertukarkan dalam pemerintahan kolonial (Kellner, 2004: 23-24).

Makanan merupakan ranah budaya dalam kehidupan sehari-hari yang telah sangat dipengaruhi oleh globalisasi. Makanan menghubungkan manusia, dan mungkin semua makhluk hidup, oleh kebutuhan umum untuk itu semua. Hal ini dalam banyak hal yang biasa, tetapi penting untuk semua. Kenyataan adanya hasil konstruksi melalui komunikasi lintas budaya, antara lain dengan tersebarnya resto cepat 
saji McDonald yang dapat ditemukan di lebih dari 115 negara di dunia. George Ritzer menciptakan istilah"McDonaldization" untuk menyebut masyarakat yang mencerminkan pengaruh restoran cepat saji di seluruh dunia. Dengan penyebaran dan pertukaran makanan, masing-masing pihak dan budaya diletakkan dalam kontak dengan yang lain, dan saling memengaruhi.

Makanan saat ini terintegrasi ke dalam globalisasi kapitalis, yang belum pernah terjadi sebelumnya. Semua macam makanan, dari daging atau buah-buahan tropis merupakan barang mewah yang kini beredar di seluruh dunia, selalu tersedia tanpa memperhatikan musim atau lokasi. Makanan mencerminkan identitas budaya dan dapat menciptakan batas-batas dan perbedaan antara budaya. Makanan menjadi salah satu cara yang paling dasar dan umum bagi seseorang untuk membedakan diri dari orang lain atau untuk masyarakat atau budaya untuk membedakan diri dari lain.

\section{Kuliner Indonesia Sebagai Identitas Budaya}

\section{Multikultur.}

Dari uraian tentang kuliner yang merupakan identitas budaya multikultur secara global, kuliner Indonesia pun tidak luput dari pengaruh komunikasi lintas budaya tersebut. Kuliner Indonesia memiliki spektrum yang sangat luas, dengan bentangan kepulauan Nusantara dan memiliki lokasi strategis untuk terwujudnya dialog antar bangsa, dan yang terpenting memiliki kekayaan hayati yang dapat ditrasformasikan menjadi bahan makanan. Kuliner Indonesia perlahan mulai mendunia karena memiliki citarasa yang beragam dan unik. Penyajian secara tradisional dengan menggunakan daun pisang, janur (daun kelapa yang masih kucup), dan daun pandan menarik perhatian banyak kalangan dari mancanegara.

Dalam perkembangannya kuliner tradisional berubah menjadi kuliner non-tradisional yang terjadi melalui proses komunikasi lintas budaya dalam kolonialisasi dan globalisasi. Dengan melakukan studi pustaka, penulis menemukan adanya proses mimikri dalam kuliner Indonesia terdapat pada hidangan kalangan bangsawan yang memiliki kedekatan dengan kalangan pejabat kolonial Belanda.

Konsep mimikri dalam teori pascakolonial dikemukakan oleh Homi K. Bhabha dalam buku The Location of Culture. Menurut Bhabha, mimikri kolonial adalah suatu hasrat dari subjek yang berbeda menjadi subjek sang lain yang hampir sama, tetapi tidak sepenuhnya sama (as subject of a difference, that is almost the same, but not quite). Peniruan yang dilakukan pribumi atas penjajah Belanda lebih banyak melalui gaya hidup, yang menurut Bhabha sebagai hasrat masyarakat terjajah untuk menyesuaikan diri dengan tuntutan keadaan untuk mencapai kemajuan, dan menempatkan diri setara dengan bangsa penjajah. Hasrat dari terjajah untuk mendapat kesejajaran dengan penjajah, menjadi dasar konsep mimikri. Dalam konsep mimikri, selintas seakan meniru penjajah (colonizer), padahal sebenarnya merupakan sikap perlawanan terjajah (colonized) untuk mendapatkan kesejajaran dengan penjajah. Bhabha menyatakan bahwa mimikri merupakan upaya mengukuhkan dan sekaligus mendistorsi otoritas penjajah. Mimikri menunjukkan ketidaktergantungan terjajah terhadap penjajah. Terjajah menikmati adanya ambivalensi yang terjadi pada proses mimikri, sebagai strategi menghadapi dominasi penjajah. Konsep mimikri dari Homi Bhabha untuk mengulas kuliner Indonesia, yang merupakan suatu perpaduan yang nyata dalam gaya hidup dan dalam cara berpikir.

Secara ringkas kuliner Indonesia sebagai identitas budaya multikultur terdapat dalam tabel 1.

Peran kolonialisme dalam perubahan kuliner, nyata nampak dalam kuliner Indonesia. Contoh pada masa kolonial, Kartini telah membuat buku masakan yang merupakan bentuk mimikri dari hidangan Belanda. Penulis memaknai keputusan Kartini membuat buku resep adalah upaya mengonstruksikan adat atau kebiasaan bersantap orang Jawa dengan paradigma Eropa. Hal ini sebagai bentuk upaya penyejajaran martabat dengan budaya kolonial Belanda. Misalnya resep 'bestik' yang merupakan mimikri dari 'steak'. Selintas hampir sama, perbedaan ada perubahan sausnya yang disesuaikan dengan citarasa orang Jawa. Di kalangan Mangkunegaran dan Kraton Kasunanan Solo, mimikri dari steak menjadi selat solo. Contoh yang menarik untuk ditampilkan adalah custard pudding yang bermimikri menjadi klappertart di Minahasa, Sulawesi Utara. Juru masak Kraton Yogya melakukan mimikri menjadi manuk enom. Manuk Enom (artinya burung muda), nama hidangan penutup dalam jamuan makan di Kraton Yogyakarta, dicetak dalam ukuran bulat diameter $5 \mathrm{~cm}$ dan diberi hiasan emping goreng sehingga menyerupai burung. Bahan pembuatnya: telur, susu, santan kelapa, dan tape ketan hijau, sehingga menghasilkan semacam puding lembut berwarna kuning muda kehijauan. Resep tersebut penulis dapat dari buku Kekayaan Kuliner Yogyakarta, Kersanan Dalem ( 2010). 
Tabel 1. Kuliner Indonesia sebagai identitas budaya

\begin{tabular}{|c|c|c|}
\hline & Jenis & Contoh \\
\hline \multirow{2}{*}{$\begin{array}{l}\text { Kuliner } \\
\text { Tradisional }\end{array}$} & $\begin{array}{l}\text { Makanan yang menggunakan bahan } \\
\text { pangan dari alam sekitar dan cara } \\
\text { memasak masih secara tradisional }\end{array}$ & $\begin{array}{l}\text { Makanan dari masyarakat } \\
\text { yang tinggal dipelosok } \\
\text { pedesaan dan makanan } \\
\text { yang digunakan dalam ritual } \\
\text { adat }\end{array}$ \\
\hline & $\begin{array}{l}\text { Makanan yang menggunakan bahan } \\
\text { pangan dari alam sekitar dan cara } \\
\text { memasak menggunakan peralatan } \\
\text { masak modern }\end{array}$ & $\begin{array}{l}\text { Soto, rendang, gudeg yogya, } \\
\text { lontong, ketupat, srabi, } \\
\text { lemper, bubur sumsum }\end{array}$ \\
\hline \multirow{3}{*}{$\begin{array}{l}\text { Kuliner Non- } \\
\text { tradisional }\end{array}$} & $\begin{array}{l}\text { Makanan hasil proses mimikri (peniruan) } \\
\text { dalam kolonialisasi }\end{array}$ & $\begin{array}{l}\text { Selat Solo, Klappertaart, } \\
\text { Manuk Enom }\end{array}$ \\
\hline & Makanan hasil silang budaya & $\begin{array}{l}\text { Sate, nasi goreng, gulai, nasi } \\
\text { kuning }\end{array}$ \\
\hline & $\begin{array}{l}\text { Makanan asing yang telah disesuaikan } \\
\text { dengan selera Indonesia dalam globalisasi }\end{array}$ & $\begin{array}{l}\text { KFC dihidangkan dengan } \\
\text { nasi dan chili sauce, Pizza } \\
\text { dengan topping rendang } \\
\text { daging sapi }\end{array}$ \\
\hline
\end{tabular}

Sumber: Diolah oleh penulis

Ketiga hidangan penutup ini menggunakan bahan dasar sama, yaitu paduan susu, telur, dan gula. Custard Pudding berpadu dengan caramel. Di Minahasa sentuhan caramel diganti dengan kelapa muda dan kenari, dan diberi aroma kayu manis. Sedangkan di Yogyakarta menjadi hidangan penutup yang unik dengan tambahan tape ketan hijau dan santan kelapa, juga tanpa caramel.

\section{Gambar 3. Contoh Makanan Tradisional dan Non- tradisional}

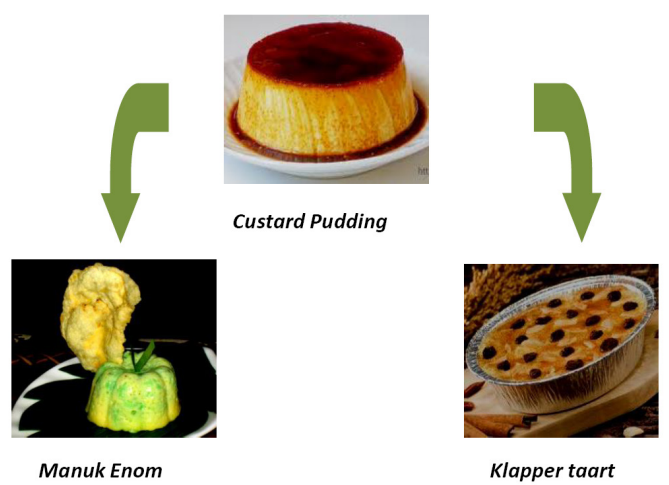

\section{Custard Pudding Manuk Enom Klapper taart}

(Sumber: Diolah oleh penulis)

Walau tetap "almost the same, but not quite", hal ini merupakan upaya agar tidak berbeda dengan Belanda, seraya menunjukkan bahwa bahan makanan dari alam pribumi bisa tampil setara dengan bahan olahan yang digunakan Belanda. Proses mimikri tidak hanya berhenti pada peniruan hidangan kolonial Belanda saja, namun pada saat ini, bergeser dengan mimikri pada makanan Barat lainnya, termasuk dari Amerika, juga dari Jepang, India, Arab, dan negaranegara yang memiliki kekhasan dalam kulinernya.

Proses peniruan menunjukkan adanya relasi kuasa dalam komunikasi lintas budaya yang menerpa kuliner di Indonesia. Adanya terpaan media massa yang tiada henti yang secara tak langsung memunculkan hegemoni budaya dari negara yang memiliki kekuatan dalam politik dan ekonomi.

Dampak dari adanya kekuasaan di balik komunikasi, memacu perubahan dalam kuliner Indonesia. Misalnya, gado-gado diberi penambahan sayuran seperti romaine lettuce dan daun basil agar lebih wangi dan bergaya Barat. Hidangan tradisional Indonesia disajikan dalam sederet hidangan yang dikenal sebagai rijstafel. Hal ini merupakan 'fusion', sehingga makanan tradisional Indonesia akan semakin kaya variasi, dan mengarah pada modernisasi. Kuliner di Indonesia mulai bergeser mengikuti perkembangan budaya dalam globalisasi.

\section{SIMPULAN}

Keterlindanan kuliner sebagai identitas budaya dalam globalisasi dengan komunikasi lintas budaya 
merupakan proses konstruksi yang terus terjadi tanpa henti. Identitas budaya tidak pernah stabil dan terus berfluktuasi. Penulis memaknainya sesuai metafor yang diungkapkan Zygmunt Bauman dalam A Shot History of Identity yang menyatakan, "walau seolah-olah identitas adalah kata benda, tetapi berperilaku seperti kata kerja. Meski janggal untuk memastikannya, karena terjadi dalam konteks masa depan." Metafor ini sejalan dengan pernyataan Brian Street: culture is not a noun, but a verb. Jadi jelas bahwa kuliner sebagai identitas budaya merupakan keniscayaan yang aktif, bergerak, akan selalu mengalami perubahan.

Dalam perkembangannya kuliner sebagai identitas budaya menunjukkan adanya lompatan orientasi masyarakat dari orientasi harmoni ke orientasi materi. Tiada yang dapat dianggap sepele tentang kuliner yang ada pada saat ini. Kuliner memberi wawasan dalam cakupan perubahan pada konteks sosial, budaya, politik, dan ekonomi dalam masyarakat dunia. Kuliner merupakan salah satu cara paling mudah dan langsung untuk mempromosikan pemahaman multikultural.

Dikaitkan dengan multikulturalisme, Indonesia dapat digambarkan sebagai sebuah mozaik yang amat luas yang terdiri atas semua peradaban dari semua komponen bangsa ini. Dalam hal ini saya sepakat bahwa perlu adanya kesadaran baru dalam 'membaca' kuliner sebagai identitas budaya, yang terus menerus mengalami proses 'menjadi' dalam ruang dan waktu. Kita memang harus terus membangun kesadaran kritis ini terhadap multikulturalisme yang berdimensi etis, yang menuntut tanggung jawab moral berupa pengakuan, rasa hormat, dan empati atas kehadiran orang lain. Hal ini bukan paksaan, karena yang ditekankan adalah suatu kesadaran.

Dengan latar keadaan seperti itu, dapat dipahami bahwa Indonesia tak dapat menghindar dari pengaruh peradaban dunia. Peradaban Indonesia saat ini menjadi peradaban yang banyak terwarnai dan mewarnai peradaban dunia. 'Kekinian dan kesinian' terus dengan cepat bergulir dalam semua aspek kehidupan. Termasuk pada konstruksi sosial terhadap kuliner Indonesia sebagai identitas budaya bangsa. Hal ini semakin jelas percepatan prosesnya dengan adanya keterbukaan media massa yang dipacu kemajuan teknologi informasi, dan adanya unsur kekuasaan di dalamnya.

\section{DAFTAR PUSTAKA}

Alcoff, L.M. \& Mendieta, E. (Eds). (2000). Identities: Race,Class, Gender, and Nationality.UK: Blagckwell Publishing.

Bentley, A. (2007). Culinary Other. London: Polity Press.

Bhabha, H.K. (1994). The Location of Culture, London: Routledge.

Castel, M. (1997). The Power of Identity.Oxford: Blackwell Publishing.

Hall, S. (1994). The Question of Cultural Identity. : London: Sage Publication

Kellner, D. (2004). Globalization and The Postmodern Turn'. Los Angeles: UCLA.

Lawler, S. (2008). Identity: Sociological Perspectives. Maiden, USA: Polity Press

Meigs, A. (1997). Food as a Cultural Construction. In Counihan, C., \& van Esterik, P. (Eds.), Food and Culture: A Reader. New York: Routledge.

Mulyana, D. dan Rakhmat, J. (ed). (2010). Komunikasi Lintas Budaya. Bandung: PT. Remaja Rosdakarya.

wa Thiong'o, N. (1986). Decolonising the Mind: The Politics of Language in African Literature. London: James Currey.

Samovar, L.A. \& Porter, R.E. (1991). Communications Between Cultures. California: Wodsworth Publishing Company.

Street, B. (1993). Culture is a verb. In Graddol, D., Thompson, L., \& Byram, M. (Eds.). Language and Culture, Clevedon: BAAL and Multilingual Matters.

Tomlinson, J. (2007). Globalization and Cultural Analysis. In Held, D., \& MacGrew, A. (Eds.), Globalization Theory: Approaches and Controversies. Cambridge: Polity.

Woodward, K. (1999). Identity and Difference. London: Sage Publication. 